\title{
INDICES OF METAL PROTEINS (TRANSFERRIN, CERULOPLASMIN) IN OVERWEIGHT AND OBESE CHILDREN
}

\section{Tamila V. SOROKMAN ${ }^{1 \otimes}$, Snizhana V. SOKOLNYK ${ }^{1}$, Alexandra-Maria V. POPELYUK ${ }^{2}$, Sergii 0. SOKOLNYK ${ }^{3}$, Olena V. MAKAROVA ${ }^{4}$, Volodymyr V. BEZRUK ${ }^{5}$}

${ }^{1}$ Department of Pediatrics and Medical Genetics, Bukovinian State Medical University, Chernivtsi, Ukraine

${ }^{2}$ Department of Human Anatomy, "Mykola Turkevich" Bukovinian State Medical University, Chernivtsi, Ukraine

${ }^{3}$ Department of Pediatric Surgery and Otolaryngology, Bukovinian State Medical University, Chernivtsi, Ukraine

${ }^{4}$ Department of Higher Nursing Education, Bukovinian State Medical University, Chernivtsi, Ukraine

${ }^{5}$ Department of Pediatrics, Neonatology and Perinatal Medicine, Bukovinian State Medical University, Chernivtsi, Ukraine

Received 07 March 2019, Corrections received 02 May 2019, Accepted 09 May 2019

https://doi.org/10.31688/ABMU.2019.54.2.12

\section{Abstract}

Introduction. A progressive increase of obesity prevalence, both among adults and children, is observed in many countries. Today, obesity is seen as a chronic systemic inflammation with low activity. Currently, new data are available about the biological and clinical significance of metal proteins in the inflammatory processes.

The objective was to study the transferrin and ceruloplasmin indices in overweight and obese children.

Material and methods. We have examined children with excess body weight (EBW, 30 children), obesity (40 children) and 30 healthy children aged $13-18$ years. The evaluation included history, anthropometric data (height, body weight, body mass index, waist-to-thigh ratio - WTR), serum glucose, insulin, HOMA-IR

\section{Résumé}

Les indicateurs de protéines métalliques (transferrine, céruloplasmine) chez les enfants avec surpoids et obésité

Introduction. Dans tous les pays, on observe une augmentation progressive du nombre de patients obèses, tant chez les adultes que chez les enfants. Aujourd'hui, l'obésité est considérée comme une inflammation systémique chronique de faible activité. Actuellement, il existe une accumulation d'informations sur la signification biologique et clinique des protéines métalliques dans ce processus inflammatoire.

But. Étudier les effets de la transferrine et de la céruloplasmine chez les enfants avec surpoids et obèses. 
calculation, transferrin (TF) and ceruloplasmin (CP). For statistical analysis of the results, statistic modules of Statistica v.6.0, MedStat and on-line SISA calculator were used.

Results. In a total sample of 325 children, excess body weight was observed in $75(23.1 \%)$ cases and obesity in $68(13.6 \%)$ children. Boys prevailed, with 40 (53.3\%) cases of EBW among those and 38 (55.8\%) with obesity. The content of TF and CP in children aged $16-18$ years was higher $(28.1 \pm 0.8 \mathrm{mg} / \mathrm{dL}$ and $3.90 \pm 0.70 \mathrm{~g} / \mathrm{L}, \mathrm{n}=22, \mathrm{p}<0.05)$ than in children aged $13-15$ years. The highest TF level $(3.98 \pm 0.9 \mathrm{~g} / \mathrm{L}, \mathrm{n}=$ $16)$ and CP level $(28.9 \pm 0.8 \mathrm{mg} / \mathrm{dL}, \mathrm{n}=16)$ were recorded in children with grade II obesity. There was no apparent difference either in the gender indices of TF and CP, nor in obese children combined with insulin resistance or obesity without insulin resistance. Less obvious changes in TF and CP were found in children with EBW. The weak relationships between the increase in $\mathrm{BMI}$ in children and the $\mathrm{CP}$ and $\mathrm{TF}$ ( $\mathrm{r}$ $=0.28 ; \mathrm{p}<0.001)$ level in the blood plasma of obese children $(r=0.23$; $\mathrm{p}<0.0001)$ were detected, though they are highly statistically significant.

Conclusions. Early identification of children with EBW and monitoring of their health, including the assessment of systemic inflammation markers, is an up-to-date and promising area for optimizing the obesity prophylaxis.

Keywords: children, excess body weight, obesity, ceruloplasmin, transferrin.

\section{INTRODUCTION}

Obesity is a disease of a particular concern and one of the most serious public health problems in many countries ${ }^{1-3}$. A progressive increase of obesity prevalence both among adults and children, has been observed in countries such as USA'-6, Canada ${ }^{7}$, $\mathrm{UK}^{8}$, Denmark ${ }^{9}$, India ${ }^{10}$, Australia ${ }^{11}$. The combined prevalence of excess body weight and obesity ranges from $40 \%$ in Southern Europe to $10 \%$ in Northern Europe. In general, the prevalence of excess body weight is higher in girls (21.1\%) compared to boys $(18.6 \%)^{12}$. According to official statistics, the average prevalence of obesity among children in Ukraine in 2016 was 13.44 per 1000 children, with variations in the regional aspect from 6.49 in Lugansk and 8.04 in Odesa to 22.87 in Ternopil and
Materiel et méthodes. Nous avons examiné les enfants en surpoids (IMC, 30 personnes), l'obésité (40 personnes) et 30 enfants en bonne santé âgés de 13 à 18 ans, incluant: l'anamnèse, l'anthropométrie (taille, poids corporel, IMC, ratio OT / OS), le contenu de glucose, insuline, calcul HOMA-IR, teneur en transferrine (TF) et céruloplasmine (CP). Pour l'analyse statistique des résultats, nous avons utilisé les modules des statistiques Statistica v.6.0, MedStat et le calculateur SISA en ligne. Résultats. Sur un échantillon total de 325 NMT, 75 enfants (23,1\%) présentaient du surpoids et l'obésité a été trouvée chez 68 enfants (13,6\%). Parmi eux, les garçons avaient le dessus: $40(53,3 \%)$ d'entre eux étaient atteints de DMO et $38(55,8 \%)$ d'obèsité. La teneur en TF et en PC chez les enfants âgés de 16 à 18 ans était plus élevée $(3,90 \pm 0,70 \mathrm{~g} / \mathrm{L}, \mathrm{n}=22, \mathrm{p}<0,05)$. $\mathrm{La}$ teneur en FT la plus élevée $(3,98 \pm 0,9 \mathrm{~g} / \mathrm{L}, \mathrm{n}=16)$ et la PC $(28,9 \pm 0,8, n=16)$ ont été enregistrées chez des enfants obèses de degré II. Il n'y a pas de différence apparente entre les indices de TF et de PC et le sexe chez les enfants obèses, en association avec la résistance à l'insuline et l'obésité sans résistance à l'insuline. On observe des changements moins prononcés dans le TF et le CP chez les enfants atteints de BMT. La signification statistique faible mais élevée de la relation entre l'augmentation de l'IMC chez les enfants et la PC et le TF $(r=0,28 ; p<0,001)$ dans le plasma sanguin des enfants obèses $(r=0,23 ; p<0,0001)$.

Conclusions. La détection précoce des enfants atteints de TMN et le suivi de leur santé, y compris l'évaluation des marqueurs inflammatoires systémiques, constituent un domaine prometteur et moderne pour optimiser le système de prévention de l'obésité.

Mots-clés: enfants, excès de poids, obésité, céruloplasmine, transferrine.

27.39 in Vinnytsia regions ${ }^{13-15}$. The prevalence rate of children with excess body weight in Ukraine is unknown, as statistical analysis of EBW in Ukraine is not conducted ${ }^{16}$. However, obesity in children is of particular relevance, as it leads to the development of various complications, as well as diseases associated with atherogenic dyslipidemia, and may be also a risk factor for death in adults, along with other causes ${ }^{17-19}$.

Prevention of obesity in childhood is recognized as one of the main tendency to primary prophylaxis of non-communicable diseases, since adult obesity in most cases originates from childhood ${ }^{20-21}$. The decrease of the prevalence of EBW and obesity among adolescents is formalized by an additional indicator of the corresponding target benchmark in the program document "Health 2020"22 
Today, obesity is seen as a chronic systemic inflammation with low activity. Leptin and 12 inflammatory parameters (interleukin [IL]-2, IL-4, IL-6, IL-8, IL-10, vascular endothelial growth factor, interferon-gamma [IFN- $\gamma$ ], tumor necrosis factor-alpha, IL-1 $\alpha$, IL-1 $\beta$, monocyte chemotactic protein-1 and epidermal growth factor) were measured from fasting blood samples $^{23}$. Oxidative stress, inflammation and insulin resistance are the main culprits of children's obesity. One of the tasks of modern medicine is to find new markers that allow to deal with issues of early diagnosis to prevent destructive changes in the body, to predict the severity and course of illness, to timely detect their complications, and foremost to evaluate the effectiveness of conservative therapy. The researchers' data show that the information about the biological and clinical significance in the inflammation process of metal proteins such as ceruloplasmin (in a population of adolescents with metabolic syndrome $e^{24}$, from overweight and obese subjects ${ }^{25}$, in insulin-dependent diabetes mellitus ${ }^{2628}$, in patients with osteoporosis ${ }^{29}$, ferritin, transferrin ${ }^{30.32}$ is in great demand, as metal proteins are blood proteins that take part in depositing, transporting and disinfecting metal ions of variable valency. The importance of the research of the proteins lies in their role in the antioxidant system's functioning. Transferrin belongs to the negative proteins of the acute phase, because its content is reduced during inflammation, while ceruloplasmin is a positive protein, because its level during inflammation increases ${ }^{33-34}$.

The obJective of THE Study was to evaluate transferrin and ceruloplasmin indices in EBW and obese children.

\section{Material AND MEthods}

In the study, medical forms $026 /$ o "Child's medical card" of 325 children aged 13-18 who were treated at Chernivtsi Oblast Children's Clinical Hospital, Ukraine, within 2016-2018, have been analyzed. A group of adolescents with EBW (30 children) and obesity (40 children) was formed, that made up the experimental group. The control group included 30 healthy adolescents with standard body weight of the same age without complaints, clinical signs and anamnestic data that would indicate the presence of any chronic disease.

All studies were conducted after the informed consent was signed by the children and their parents. The work follows the ethical principles of the people who act as subjects of the study taking into account the main provisions of the ICH GCR and the Helsinki Declaration of the World Medical Association for Biomedical Research, where a person acts as their object (World Medical Association Declaration Helsinki 1964, 2000, 2008), The Council of Europe Convention on Human Rights and Biomedicine (2007).

The inclusion criteria into the experimental group were the presence of EBW or obesity. The exclusion criteria were: congenital endocrine and renal disease, secondary arterial hypertension, prolonged hormonal therapy (over 1 month), type 1 diabetes mellitus, and patients under 13 years.

Children were put into 2 age groups: $13-15$ years old and 16-18 years old. In both groups, history was taken, among which anthropometry (height, body weight, body mass index - BMI, waist circumference - WC, hip circumference - HC, waist-to-thigh ratio (WTR) calculation) and laboratory tests were conducted. Verification of obesity and EBW was confirmed according to BMI in percentile tables: BMI in the $85-95^{\text {th }}$ percentile was considered as excess weight, over 95 percent percentile - as obesity, from 5 to 85 percentiles as normal body weight.

Insulin resistance was detected by measuring the HOMA index (HOMA-IR). Blood insulin content was measured by radioimmunological assay using Insulin IRMAKIT kits, Beckman Coulter (Czech Republic). Blood glucose concentration was detected using biosensor electrochemical analysis on a SuperGL device (Germany) and Glucocapil (Germany) sets. The content of transferrin in serum was detected by immuno-turbidimetric method (TRSF Tina-quant Transferrin ver.2.Roche / Hitachi cobas c 311). Serum levels were detected with the AssayMax Human Ceruloplasmin ELISA Kit (ELISA, Webster, Texas, USA) at the Stat Fax 2100 Biochemical Analyzer.

Statistical analysis of the results (quantitative and qualitative analysis with the calculation of the average and relative values, identification of statistical significance by the $\chi 2$ criterion for absolute values as well as with the Fisher's angle transformation method $\mathrm{p} \phi$ for relative values) was conducted with statistical modules such as Statistica v.6.0 and MedStat and on-line SISA calculator (Simple Interactive Statistical Analysis), using correlation and parametric analysis. Average values are given as $(M \pm m)$, where $M$ is the average value of the index, $m$ is the standard error of the mean; $\mathrm{n}$ - the number of the experimental group. The estimation of interconnections between different indices was carried out using the correlation analysis with the Pearson's criterion (rxy). Differences were considered statistically significant at $\mathrm{p}<0.05$. 
Table 1. Indices of BMI, WTR, HOMA-IR index, levels of transferrin and ceruloplasmin in the examined children

\begin{tabular}{|c|c|c|c|c|c|}
\hline \multirow{2}{*}{ Indicator } & \multicolumn{2}{|c|}{$\begin{array}{c}\text { Children } 13-15 \text { years old } \\
n=33\end{array}$} & \multicolumn{2}{|c|}{$\begin{array}{l}\text { Children } 16-18 \text { yearsold } \\
\mathrm{n}=37\end{array}$} & \multirow{2}{*}{$\begin{array}{l}\text { Healthychildren } \\
\qquad n=30\end{array}$} \\
\hline & $\begin{array}{c}\mathrm{EBW} \\
\mathrm{n}=15\end{array}$ & $\begin{array}{l}\text { Obesity } \\
\mathrm{n}=18\end{array}$ & $\begin{array}{c}\mathrm{EBW} \\
\mathrm{n}=15\end{array}$ & $\begin{array}{l}\text { Obesity } \\
\mathrm{n}=22\end{array}$ & \\
\hline WTR & $0.80 \pm 0.01^{*, * *}$ & $0.93 \pm 0.01^{*, * *}$ & $0.89 \pm 0.03^{*}$ & $0.98 \pm 0.01^{*}$ & $0.74 \pm 0.02$ \\
\hline BMI & $26.6 \pm 0.4^{*}$ & $36.1 \pm 1.1^{*, * *}$ & $28.9 \pm 0.8^{*}$ & $39.7 \pm 1.2^{*}$ & $18.8 \pm 0.9$ \\
\hline HOMAIR & $2.05 \pm 0.11^{*}$ & $2.56 \pm 0.10^{*, * *}$ & $2.19 \pm 0.11^{*}$ & $2.87 \pm 0.12^{*}$ & $1.79 \pm 0.11$ \\
\hline $\mathrm{CP}, \mathrm{mg} / \mathrm{dl}$ & $16.5 \pm 1.1^{*, * *}$ & $19.9 \pm 1.1^{*, * *}$ & $20.5 \pm 0.9^{*}$ & $28.1 \pm 0.8^{*}$ & $15.4 \pm 0.8$ \\
\hline TF, г/л & $1.8 \pm 0.6^{* *}$ & $2.2 \pm 0.8^{*, * *}$ & $2.8 \pm 0.9^{*}$ & $3.9 \pm 0.7^{\star}$ & $1.7 \pm 0.3$ \\
\hline
\end{tabular}

Notes: WTR -waist-to-thigh ratio; BMI - body mass index; HOMA-IR - index of insulin resistance; EBW - excess body weight; $\mathrm{CP}$ - ceruloplasmin; TF - transferrin; ${ }^{*}$ - the significance is between the indicators in children with EBW and obesity in contrast to healthy children ${ }^{* *}$ - the values are between the indices in children 13-15 years and children 16-18 years at $\mathrm{p}<0.05$.

\section{RESULTS}

In the total sample of 325 cases, 75 (23.1\%) children with EBW and 68 (13.6\%) children with obesity were included. Among them, boys prevailed, with 40 (53.3\%) among those with EBW and 38 (55.8\%) among those with obesity. Analyzing the age of the examined patients, EBW and obesity were most commonly recorded among boys aged over 17 years $(59.4 \%)$ and girls aged $15-16$ years $(64.2 \%, \mathrm{p} \phi<0.05)$. All obese patients had diet violations in anamnestic data. Diet violation was found in $25 \%$ in the group of adolescents without obesity. Indices of BMI, WTR, HOMA-IR index, levels of transferrin and ceruloplasmin of patients with age correlation are shown in Table 1.

A difference in the indices of transferrin in obese children correlated with age. The higher content of transferrin was detected in children aged $16-18$ years $(3.90 \pm 0.70 \mathrm{~g} / \mathrm{L}, \mathrm{n}=22, \mathrm{p}<0.05)$. The highest content of transferrin was recorded in children with obesity grade II $-3.98 \pm 0.9 \mathrm{~g} / \mathrm{L}, \mathrm{n}=16$ versus $3.05 \pm 0.61 \mathrm{~g} / \mathrm{L}$, $\mathrm{n}=24, \mathrm{p}<0.05$ in children with $\mathrm{I}^{\mathrm{st}}$ degree obesity.

A similar tendency has been identified in the parameters of ceruloplasmin in the blood plasma of examined children. Thus, higher values of ceruloplasmin were detected in children with II ${ }^{\text {nd }}$ degree obesity $-28.9 \pm 0.8 \mathrm{mg} / \mathrm{dL}, \mathrm{n}=16$ versus $25.8 \pm 0.7 \mathrm{mg} /$ $\mathrm{dL}, \mathrm{n}=24, \mathrm{p}<0.05$ in children with ${ }^{\text {st }}$ degree obesity and in children aged $16-18$ years $-28.1 \pm 0.8 \mathrm{mg} / \mathrm{dL}, \mathrm{n}$ $=22$ vs. $19.8 \pm 1.2 \mathrm{mg} / \mathrm{dL}, \mathrm{n}=18, \mathrm{p}<0.01)$ in children 13-15 year-old. There was not detected a significant difference in the gender ratios of transferrin and ceruloplasmin (Fig. 1).

Obesity was combined with insulin resistance (HOMA-IR ranged from 2.52 to 2.89 and averaged $2.69 \pm 0.9)$ in $18(45 \%)$ children. Moreover, the increased HOMA-IR index was more common in children with grade II obesity. The HOMA-IR index exceeded the norm and averaged $2.78 \pm 0.4$ in 13 out of 16 children with obesity grade II (81.2\%), whereas the degree of combination with insulin resistance in obese children, was found in only 5 children with $24(20.8 \%, \mathrm{p} \phi<0.01)$ cases with an average HOMA-IR of $2.58 \pm 0.2$.

The difference in the values of ceruloplasmin and transferrin in obese and insulin-resistant children with obesity without insulin resistance was not detected.

Less pronounced changes in ceruloplasmin and transferrin were observed in children with EBW (Fig. 2). The levels of metal proteins were within reference values in both boys and girls aged 13-15 years. However, the indices of ceruloplasmin and transferrin in children aged $16-18$ years had a tendency to increase ( $p>0.05)$.

The correlation analysis revealed a high statistical significance of the relationship between the increase in BMI in children and the values of ceruloplasmin in the blood plasma of obese children $(\mathrm{r}=$ $0.23 ; \mathrm{p}<0.0001)$ and transferrin $(r=0.28 ; \mathrm{p}<0.001)$.

\section{Discussion}

During the last two decades, obesity has emerged as a leading public health problem; it is more prevalent in developed countries, affecting adults and children alike ${ }^{35}$. Currently, there are no general surveillance systems in Ukraine that provide comparisons of indices and temporary trends in the prevalence of EBW and obesity in children ${ }^{16}$. The prevalence of EBW and obesity among children depends on the sex-age structure of the children population ${ }^{35-36}$. When planning and conducting work on the prevention of obesity among children within the health care in terms of the health care institution, both the sex-age structure of the child population and the possible risks of the development of health disorders in children associated with EBW and obesity should be taken into account ${ }^{37-38}$. 


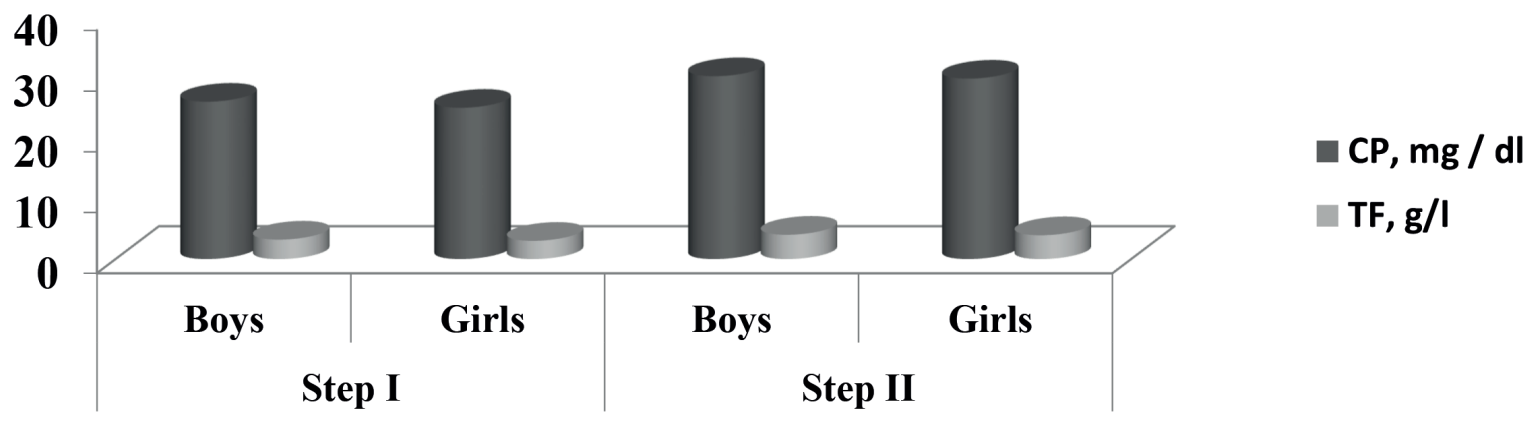

Fig. 1. Indices of transferrin and ceruloplasmin in obese children.

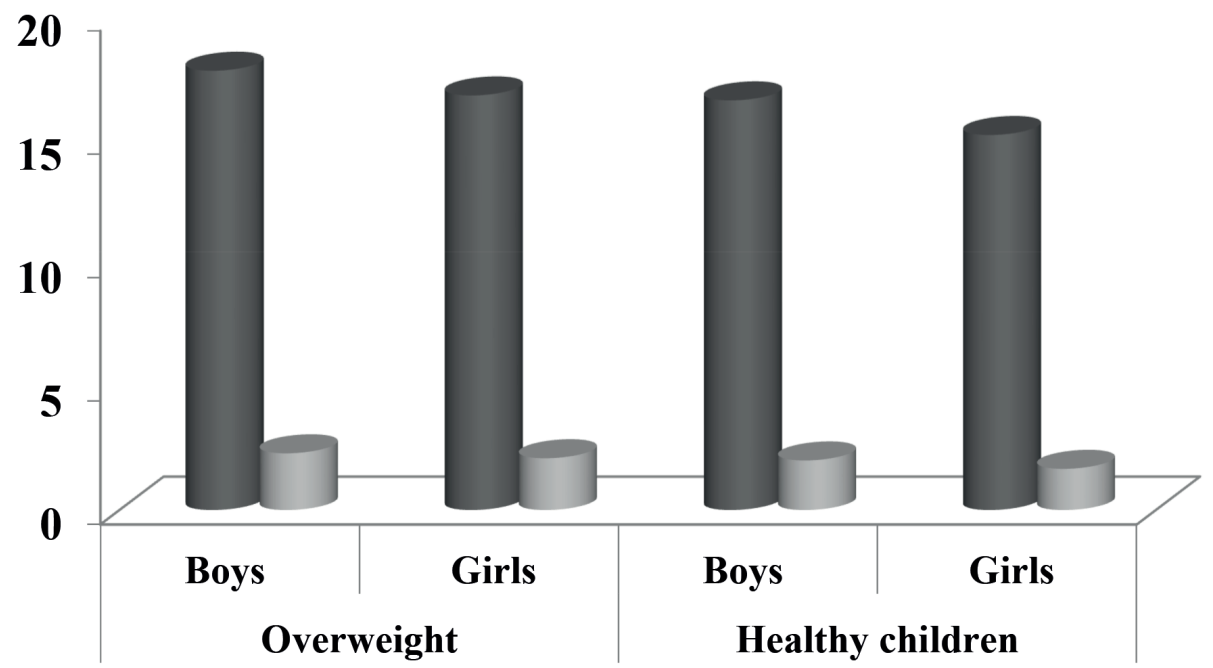

$\square \mathrm{CP}, \mathrm{mg} / \mathrm{dl}$

$\square$ TF, g/l

Fig. 2. The content of ceruloplasmin and transferrin in blood plasma of children with EBW according to gender $(p<0.05)$.

According to the results of the study, it can be assumed that markers of systemic inflammation can be used to predict the development of obesity in children with EBW and assess the obesity status in children ${ }^{39}$. The excess of macronutrients in the adipose tissues stimulates them to release inflammatory mediators such as tumor necrosis factor $\alpha$ and interleukin 6 , and reduces production of adiponectin, predisposing to a pro-inflammatory state and oxidative stress. The increased level of interleukin 6 stimulates the liver to synthesize and secrete C-reactive protein ${ }^{40-41}$.

On the other hand, the increase of ceruloplasmin in obese children can be considered as an answer to oxidative stress. It is known that there are compensatory shifts aimed at increasing the effectiveness of antioxidant protection in obese children. The reasons for such a shift may be an increase in the content of free fatty acids in the blood, as substrates for lipid peroxidation, as well as an increase in the concentration of prooxidant metabolites, in particular catecholamines. The obtained results indicate that insulin resistance does not change or affect the activity of ceruloplasmin and transferrin significantly.

\section{Conclusions}

Early detection of children with EBW and monitoring their health, including assessment of systemic inflammation markers, is an up-to-date and promising area for optimizing the obesity prevention system. Emerging changes contribute to the aggravation of the disease, especially in puberty. Mechanisms of the obesity complications (in particular, insulin resistance) may be associated with age-related features of changes in hormonal secretion in late puberty. Identification of the studied markers gains real prospects for the development of new approaches to the treatment of obesity in puberty.

\section{Compliance with Ethics Requirements:}

„The authors declare no conflict of interest regarding this article"

"The authors declare that all the procedures and experiments of this study respect the ethical standards in the Helsinki Declaration of 1975, as revised in 2008(5), as 
well as the national law. Informed consent was obtained from all the patients included in the study"

"No funding for this study"

\section{REFERENCES}

1. Global status report on noncommunicable diseases 2014 . Geneva: World Health Organization; 2014, 302 p.

2. Centers for Disease Control and Prevention. National Center for Health Statistics. Available at: http://www.cdc. gov/growthcharts/. (Accessed 17 March 2016).

3. Ogden CL, Carroll MD, Fryar CD, Flegal KM. Prevalence of obesity among adults and youth: United States, 20112014. NCHS Data Brief. 2015;(219):1-8.

4. Weedn AE, Hale JJ, Thompson DM, Darden PM. Trends in obesity prevalence and disparities among low-income children in Oklahoma, 2005-2010. Child Obes. 2014; 10(4):318-25.

5. Javed A, Jumean M, Murad MH, et al. Diagnostic performance of body mass index to identify obesity as defined by body adiposity in children and adolescents: a systematic review and meta-analysis. Pediatr Obes. 2015; 10:234-244.

6. Han JC, Lawlor DA, Kimm SY. Childhood obesity. Lancet. 2010; 375:1737-1748.

7. Chaput JP, Lambert M, Gray-Donald K, et al. Short sleep duration is independently associated with overweight and obesity in Quebec children. Can J Public Health. 2011;102:369_ 374.

8. Upton P, Taylor C, Erol R, Upton D. Family-based childhood obesity interventions in the UK: a systematic review of published studies. Community Pract. 2014;87:25-29.

9. Harder-Lauridsen NM, Birk NM, Ried-Larsen M, et al. A randomized controlled trial on a multicomponent intervention for overweight school-aged children-Copenhagen, Denmark. BMC Pediatr. 2014;14:273.

10. Arora M, Nazar GP, Gupta VK, et al. Association of breakfast intake with obesity, dietary and physical activity behavior among urban school-aged adolescents in Delhi, India: results of a cross-sectional study. BMC Public Health. 2012;12:881.

11. Franklin J, Denyer G, Steinbeck KS, et al. Obesity and risk of low self-esteem: a statewide survey of Australian children. Pediatrics. 2006;118:2481-2487.

12. Ahrens W, Pigeot I, Pohlabeln H, et al. Prevalence of overweight and obesity in European children below the age of 10. Int J Obes (Lond). 2014;38 Suppl 2:S99-107.

13. Dudina OO, Moiseienko RO, Zabolotna IE, et al. The dynamics of the health of the children's population. Annual report on the health status of the population, the sanitary and epidemiological situation and the results of the health system of Ukraine. 2016, Kyiv: Ministry of Health of Ukraine. 2017:43-69.

14. ZelinskaNB, RudenkoNH. Analysis of statistical indicators of the Children's Endocrinology Service of Ukraine in 2015. Ukrainian Journal of Pediatric Endocrinology. 2016;2:7-17.

15. Maidannyk VG, Khaitovych MV, Pavlyshyn HA, et al. Prevalence of excess body weight and high blood pressure among school-children of different regions of Ukraine. International Journal of Pediatrics, Obstetrics and Gynecology. 2013;1 (3):33-39.

16. Dyachuk Dmytro D, Zabolotna Iryna E, Yaschenko Yuri B. Analysis of the extension of childhood expectations and evaluation of the risks of the development of diseases associated with overweight. Wiad Lek. 2018;71:3.

17. Rajjo T, Mohammed K, Alsawas M, et al. Treatment of pediatric obesity: an umbrella systematic review. J Clin Endocrinol Metab. 2017;102:763-775.

18. Skinner AC, Perrin EM, Moss LA, Skelton JA. Cardiometabolic risks and severity of obesity in children and young adults. N Engl J Med. 2015;373:1307-1317.

19. Reinehr T, Wiegand S, Siegfried W, et al. Comorbidities in overweight children and adolescents: do we treat them effectively? Int J Obes. 2013; 37:493-499.

20. Huang JS, Barlow SE, Quiros-Tejeira RE, et al. Childhood obesity for pediatric gastroenterologists. J Pediatr Gastroenterol Nutr. 2013; 56:99-109.

21. Prioritizing areas for action in the field of population-based prevention of childhood obesity: a set of tools for Member States to determine and identify priority areas for action. Geneva: World Health Organization; 2012, 86 p.

22. The European health report 2015. Targets and beyond Reaching new frontiers in evidence. Copenhagen: WHO Regional Office for Europe; 2015, 150 p.

23. Jürimäe J, Võsoberg K, Tamm A-L, Maasalu K, Remmel L, Tillmann V. Body composition and inflammatory markers in pubertal girls: Comparison between athletes and non-athletic controls. European Journal of Sport Science. 2017; 17(7):867.

24. González"-Jiménez E, Schmidt-Riovalle J, Sinausía L, et al. Predictive value of ceruloplasmin for metabolic syndrome in adolescents. BioFactors. 2016; 42 (2):163-170.

25. Safavi SM, Ziaei R, Reza MM. Association of serum ceruloplasmin level with obesity: some components of metabolic syndrome and high-sensitive C-reactive protein in Iran. J Obes. 2012;2012: 951093.

26. Cunninghamn J, Leffella M, Mearklea P, Harmatz P. Elevated plasma ceruloplasmin in insulin-dependent diabetes mellitus: Evidence for increased oxidative stress as a variable complication. Metabolism - Clinical and Experimental. 1995;44(8):996 - 999.

27. Aguilar MJ, González-Jiménez E, Antelo A, Perona JS. Insulin resistance and inflammation markers: correlations in obese adolescents. J Clin Nurs. 2013;22(13-14):2002-10.

28. Dasari R, Raghunath V. Obesity and type II diabetes mellitus: is resistin the link? J Diabetes Endocr Pract. 2018; 1:1-8.

29. Karakas EY, Yetisgin A, Cadirci D, et al. Usefulness of ceruloplasmin testing as a screening methodology for geriatric patients with osteoporosis. J Phys Ther Sci. 2016; 28(1):235-9.

30. Shukla N, Maher J, Masters J, et al. Does oxidative stress change ceruloplasmin from a protective to a vasculopathic factor? Atherosclerosis. 2006;187(2):238-50.

31. Flynn AC, Begum S, White SL, et al. SCOPE and UBPEAT Consortiums. Relationships between maternal obesity and maternal and neonatal iron status. Nutrients. 2018;10(8). Pii:E1000.

32. Doğan G, Andiran N, Çelik N, Uysal S. Iron parameters, prohepcidin and soluble transferrin receptor levels in obese children. Minerva Pediatr. 2016;68(6).

33. Halitin S, Deutsch V, Tauman R. Hepcidin, soluble transferrin receptor and IL-6 levels in obese children and adolescents with and without type 2 diabetes mellitus/impaired glucose tolerance and their association with obstructive sleep apnea. J Endocrinol Invest. 2018;41(8):969-975.

34. KondoK, NoguchiM, MukaiK, et al. Transferrin receptor expression in adenocarcioma of the lung as a histopathologic indicator of prognosis. Chest. 1990;97:1367- 1371. 
35. Krzysztoszek J, Wierzejska E, Zielińska A. Obesity. An analysis of epidemiological and prognostic research. Arch Med Sci. 2015;11:24-33.

36. Kyriazis I, Rekleiti M, Saridi M, et al. Prevalence of obesity in children aged 6-12 years in Greece: nutritional behaviour and physical activity. Arch Med Sci. 2012 Nov 9; 8(5): 859-864.

37. Bialo RS, Gordon CM. Underweight, overweight, and pediatric bone fragility: impact and management. Curr Osteoporos Rep. 2014; 12(3): 319-328.
38. Ogden CL, Carroll MD, Kit BK, Flegal KM. Prevalence of childhood and adult obesity in the United States, 20112012. JAMA. 2014;311:806-14.

39. Ellulu SM, Patimah I, Khaza'ai H, et al. Obesity and inflammation: the linking mechanism and the complications. Arch Med Sci. 2017; 13(4): 851-863.

40. Bassuk SS, Rifai N, Ridker PM. High-sensitivity C-reactive protein: clinical importance. Curr Probl Cardiol. 2004;29:439-43.

41. Lafontan M. Fat cells: afferent and efferent messages define new approaches to treat obesity. Annu Rev Pharmacol Toxicol. 2004; 45:119-46. 